DOI: $10.2478 /$ ace-2014-0026

\title{
JUBILEE OF 80TH BIRTHDAY ANNIVERSARY OF JERZY ZIÓŁKO PROFESSOR AND DOCTOR HONORIS CAUSA
}

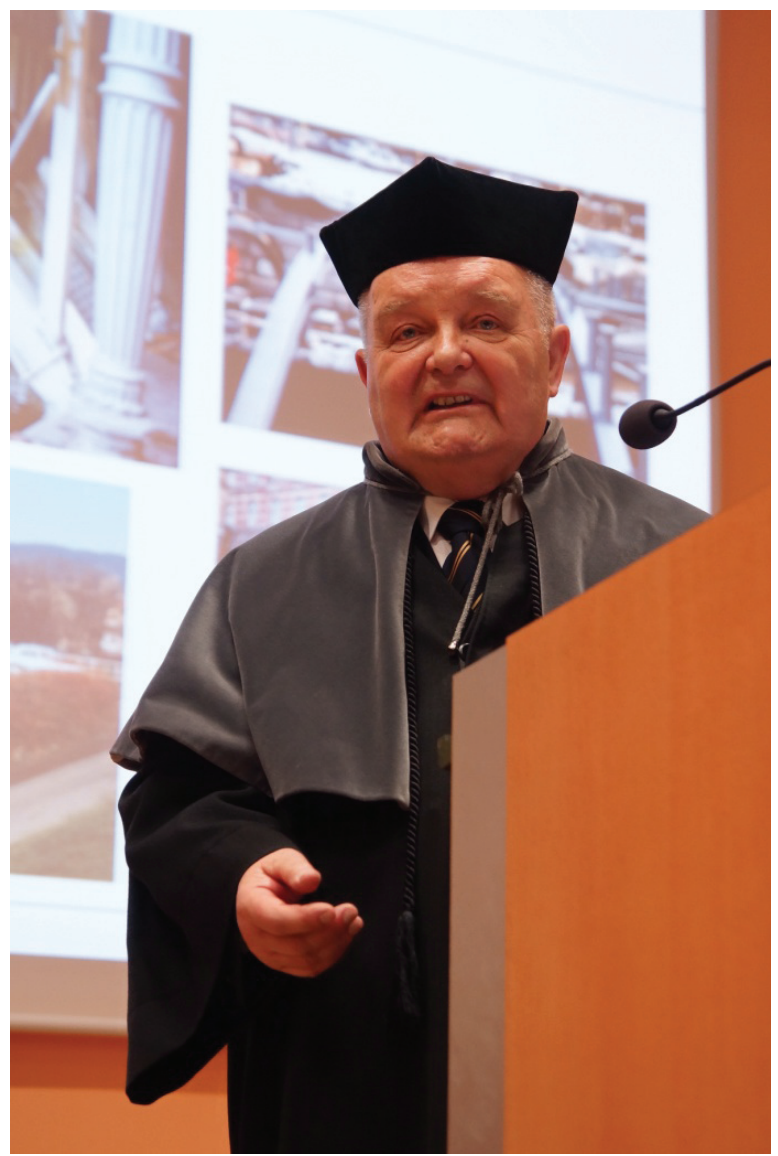

Jerzy Ziółko was born on the 29th of November, 1934 in Radom, in the civil servant family. In the years 1948-1952 he carried out his education in the Tytus Chałubiński's General Secondary School in Radom. Higher education study completed in the years 1952-1957 in the Faculty of Civil Engineering of the Gdańsk University of Technology, obtaining an MSc professional degree in Civil Engineering, in specialization Building and Civil Engineering structures. 
Right after the higher education study, he began his professional career in the Poznań Steel Structures and Industrial Equipment Company MOSTOSTAL, starting as a Construction Engineer and ending as a Chief Engineer of Work Management Group in Gdańsk. From 1958, with a year interval, worked simultaneously half-time as a technical instructor in the Department of Steel Structures of the Gdańsk University of Technology. For the longest period of professional activities, the Celebrator of a Jubilee is connected with the Gdańsk University of Technology where he worked full-time in the years 1963-2005, occupying the faculty positions from senior instructor up to full professor. Between 1969 and 1975 he was a Deputy Director and Director of the Institute of Civil Engineering, in the years 1978-1987 - a Deputy Dean of the Faculty of Civil Engineering, firstly for Academic Affairs and then for Scientific Research, as well as he led the Department of Metal Structures in the years 1994-2005. Between 1991 and 1999 he was an Editor of Scientific Publications of Gdańsk University of Technology Press. Moreover, in the years 2002-2004 he was a member of Gdańsk University of Technology Senate and between 1984 and 2005 worked in various committees of the Senate. From 1998 he worked simultaneously at the Technical and Agricultural Academy in Bydgoszcz, then from 2006 to date at the Jan and Jędrzej Śniadecki's University of Technology and Life Sciences, that emerged from the transformation of the Academy. He held an Associate Professor faculty position until 2012, and from 2012 to present - he is a Full Professor position in the Faculty of Engineering, Architecture and Environmental Engineering.

In 1964 he obtained a $\mathrm{PhD}$ academic degree in technical sciences granted by the Faculty of Civil Engineering Council of the Gdańsk University of Technology on the basis of dissertation entitled Issues related to industrialization of assembly of large capacity cylindrical steel tanks. His dissertation was awarded the $3^{\text {rd }}$ degree Individual Award in the national competition of the Minister of Higher Education and Technology. In 1979 he was granted by the State Council a title of Associate Professor in Technical Sciences. Publications of Professor Jerzy Ziółko have been distinguished and awarded. His book Steel tanks for liquids and gases ( $1^{\text {st }}$ edition published by Arkady in 1970) was awarded in 1984 a special award of the Minister of Construction and Building Materials Industry: In recognition of outstanding published scientific and technical work in the area of construction and building materials industry for the period of 40 years of Polish People's Republic. The $2^{\text {nd }}$ edition of this book, completely revised and supplemented was published by Arkady in 1986. On the basis of this edition and his entire scientific, didactic and professional achievements he was granted the Habilitated Doctor Degree in Technical Sciences (DSc academic degree) by the Faculty of Civil Engineering Council of the Gdańsk University of Technology. His crowning achievement is the title of Doctor Honoris Causa granted by the Jan and Jędrzej Śniadecki's University of Technology and Life Sciences in Bydgoszcz in 2012.

Professional and research interests of Professor Jerzy Ziółko focus on different structural and technological aspects of metal building and civil engineering structures, mostly: 
- Steel shell structures, mainly tanks for liquids and gases.

- Durability and safety of steel structures.

- Rheological aspects of mechanical properties of steel due to long-lasting exploitation.

- Methods of modern assembly, maintenance and restoration of steel structures.

The Celebrator of a Jubilee has carried out a balk of his professional and research activities within international cooperation. Professor Jerzy Ziółko has been an undisputable authority in the field of steel tanks for liquids and the creator of scientific school of design and execution of this type of industrial structures. His publication output is concerned first of all with books and chapters in edited monograph publications, as well as with papers in journals and conference proceedings. It contains of 14 books (including 4 authored individually), two of which were published in Russia (formerly Soviet Union) and one in the United Kingdom. This book output is supplemented by 213 of chapters and journal articles (including 39 in foreign journals). The most valuable cooperation in scientific and technical research has been established with Germany. In journals Stahlbau, Bauingenieur oraz Steel Construction, issued in Germany, he has published 26 papers. He is a member of Editorial Board of the journal Steel Construction - Design and Research. Together with the Leipzig University and then with the Dresden University he carried research on stability of shell structures (cylindrical silos). In the years 2005-2008 he took the leadership of a joint research project on stability of steel cylindrical silos. Research in Poland was carried out within the project funded by the Ministry of Science and Higher Education. From the German side, the project was carried out by the Leipzig University and funded by Deutschen Forschungsgemeinschaft für die Finanzielle Förderung. As a result of this joint research project, two $\mathrm{PhD}$ theses were defended, one PhD thesis defended in Germany and the other one in Poland.

Besides the journal papers published in Germany, the other ones appearing in the foreign journals were in Russia and Ukraine (formerly Soviet Union) - 8, in Hungary -2 , in Bulgaria - 1, in Croatia - 1, and in the Netherlands -1 .

Professor Ziółko was granted two short term scholarship grants, namely an over 4 months visit to the Engineering and Construction Institute in Moscow (nowadays the State University of Engineering and Construction) where he worked with Professors E.N. Lessig i E.J. Bielenia, and a month visit to the Gubkin's Institute of Oil and Gas in Moscow and Ufa. He has valued the cooperation with Russian scientists with a special estimation, among others with Professors Bogdan Wasilyevich Popovsky, one of the inventors of rolls mounting method of tanks, and with late Vsevolod Ditkovsky, and his son Alexander who invited Professor Ziółko as a honorable guest and presenter for the International Conference on Oil and Gas Tanks that took place on the ship Feodor Chaliapin during the Volga upstream voyage from Samara (in the USSR - Kuibyshev) to Nizhny Novgorod (Gorky). In late 90 . of the $20^{\text {th }}$ century he initiated the scientific cooperation with the V. N. Shimanovsky Ukrainian Institute of Steel Construction. At the beginning, the cooperation was restricted rather to the participation in the conference events taking place in Poland and in Ukraine, as well as to the lectures delivered 
for students at both countries. Later on, this initiative was transformed into the organization of Scientific-Technical Polish-Ukrainian Conference. In cooperation with the Institute of Oil Transportation in Ukraine being the general contractor for the construction project, he led the team from the Department of Metal Structures of the Gdańsk University of Technology elaborating the design project of two oil tanks in the storage Mozyr's base Homeltransnieft in Belarus. They are unique large volume eco-friendly tanks of $75000 \mathrm{~m}^{2}$, with double skin of side and bottom shells and with monitoring of an unpredictable leakage of stored oil. They were handed over to operation in 2003. Since then they have been serviced without any technical problems $\left(10^{\text {th }}\right.$ year's anniversary was celebrated by designers and executors in Mozyr). In 2004, Professor Jerzy Ziółko was elected a foreign member of the Ukrainian Academy of Civil Engineering and in 2007 - a member of the International Editorial Board of a quarterly journal Industrial Engineering and Engineering Constructions published in Kiev.

Professor Jerzy Ziółko has actively took part in foreign scientific conferences, publicizing the results of his research outcomes yielding from technical experience. In total, 37 papers were published in foreign conference proceedings. Cooperation with Slovakia resulted in a book entitled Assessment and Refurbishment of Steel Structures and published by SPON PRESS Taylor\&Francis Group. He contributed 25\% of the text of this book since it was co-authored by two Slovak Professors. The book was also published in Slovak language. English version was awarded in the area of scientific and technical books by the Slovak Literature Foundation. Technical and scientific cooperation with Hungary and Bulgaria was associated with exchange of experience and participation in scientific committees of conferences taking place in both counties involved. Professor Jerzy Ziółko was the reviewer of papers for 5 conferences taking place in Hungary and 10 held in Bulgaria as well as prepared and presented keynote lectures during these conferences.

Professor Jerzy Ziółko has been taking part in a number of activities at national level of scientific and professional life. He was the author or co-author of 121 papers published in conference proceedings and presented during the conferences held in Poland. In his publicized research, he has always been inspired by engineering practice and permanent cooperation with industry over the whole period of his professional career. Engineering practice engagement was mainly performed in the form of part-time work or within the contract work. He has an outstanding professional record. He has been the author and co-author of over 700 technical reports and expertise assessments of existing structures as well as design projects of new and modernized industrial and general purpose building structures.

Irreplaceable engineering experience of the Celebrator of a jubilee is associated with design, execution and exploitation of steel tanks for liquid and gas storage. His experience yields from many years of cooperation with Oil Pipeline Exploitation Company PRZYJAŹŃ in Płock (nowadays ORLEN Concern). Cooperation in different technical aspects of petro-chemical industry has started 20 years ago, lasted in a continuous way up to 2001 and exists also nowadays but rather as occasional events. Technical 
and scientific advice has been linked with maintenance works and modernization of oil tanks in three bases, namely in Adamowo, Płock and Gdańsk. This multiyear professional ties with Płock Oil Refinery have been supplemented by cooperation with other firms of different branches of national economy:

- Gas Plant Building Enterprise GAZOMONTAZ in Warsaw (appraiser for tanks and steel constructions - a half-time work from 1963 to 1975).

- Shipbuilding Industry Centre PROMOR in Gdańsk (steel construction consultant, including marine structures - a quarter-time work).

- BG S.A. in Wysogotowo (expert participating in the preparation of design technical documentation of tanks for NATO military aircraft industry support, on contract in the years 2007-2009).

- Energomontaż Południe S.A. in Katowice (consultant and technical advisor during construction of soccer stadium PGE Arena in Gdańsk built for European Championship in 2012 - half-time work from 2009 to 2010).

- Industria Baltic Group Gdańsk (consultant responsible for the verification of technical documentation of tanks for liquid fuels for NAFTOPORT in Gdańsk - within contract agreement in the years 2013-2014).

Professor Jerzy Ziółko has made an extensive contribution to the preparation of pioneer documents related to national codification of design in the period before introduction of Eurocodes in Poland. He is the author of Polish National Standard PN81/B-03210 Steel structures. Cylindrical vertical tanks for liquids. In the following years he led teams of experts developing the three consecutive codes for design and execution of steel cylindrical and spherical tanks. He co-edited one of the most fundamental co-authored publication on design of steel building structures according to Eurocodes. This monograph publication was elaborated within the statutory activities of the Metal Structures Section of the Civil Engineering Committee of the Polish Academy of Sciences. It was publishes by Arkady in 2010.

During work at both the Gdańsk University of Technology and the University of Technology and Life Sciences in Bydgoszcz, Professor Jerzy Ziółko educated several generations of students for civil engineering profession. He gave his scientific guidance to more than $250 \mathrm{MSc}$ theses. He trained young staff for advancing scientific degrees. He was the supervisor to 15 completed $\mathrm{PhD}$ theses. Four dissertations under the supervision of Professor Ziółko were elaborated by foreign PhD students from Syria, Yemen and Ukraine. Two of them became staff members of universities in Damascus (Syria) and Sana (Yemen). He was the reviewer in a number of assessment procedures leading towards the advancement of scientific degrees and to the scientific title: 23 for PhD degree, 9 for DSc degree and 31 for candidates aspirating to a Professor Title in Technical Sciences.

Celebrator of a jubilee was involved in activities of a number of scientific as well as professional institutions and associations, taking up important functions in many of them, among others:

- He has been elected for 7 terms (cadences) to serve as a member of the Committee for Civil Engineering of the Polish Academy of Sciences (since 1990 up to now). 
- From 1975, he has been elected to serve as a member of the Metal Structures Section of the Committee for Civil Engineering of the Polish Academy of Sciences, and acted as Deputy Chairman from 1975 to 1999, Chairman from 1999 to 2012 and since then is a Honorary Chairman.

- He was a member of the Technical Sciences Section of the Central Commission for Academic Degrees and Titles (nominated in the years 1987-1990 and elected for 5 cadences in the years 1997-2012).

- In the years 1994-2001 he was nominated to be a member of the Committee for Design and Execution of Steel Structures of the Polish Committee for Standardization.

- From 1966 he has been the member, and from 2005 a honorary member of the Polish Association of Civil Engineers and Technicians.

- For 2 terms he was an elected member of the Scientific Board of the Institute of Building Technology in Warsaw (from 2003 to 2011).

- In the years 1997-2001 he served in the State Committee for Scientific Research. Moreover, Professor Jerzy Ziółko was selected as a member of competition juries and assessing bodies. Among others, in the years 2000-2008 he was nominated by the ministry designated to supervise the civil engineering sector of national economy for the Award Committee of the best MSc diploma work as well as PhD and DSc dissertations in the field of construction, architecture and urban development. From 1996 Professor Ziółko is the member of Editorial Board for Journals and Publications in Civil Engineering of the Polish Association of Civil Engineers and Technicians (monthly journals Inżynieria i Budownictwo and Przeglad Budowlany) and the Advisory Committee of quarterly issued journal Archives of Civil Engineering and monograph publications Study in the Field of Engineering of the Committee for Civil Engineering of the Polish Academy of Sciences.

For his outstanding achievements, Professor Jerzy Ziółko has been nominated to a number of awards and honours, among other:

- 5 times between 1965 and 1982 he was granted Awards of the Minister of Science, Higher Education and Technology.

- 5 times between 1984 and 1996 he was granted Awards of the Minister supervising Civil Engineering branch of national economy.

- 40 times he was awarded by the Rector of Gdańsk University of Technology.

- in 2011 he was granted the $1^{\text {st }}$ degree Award of the Rector of University of Technology and Life Sciences in Bydgoszcz.

Furthermore, he received a number of orders and medals, the most important of which are:

- Officer's Cross of the Order of Polonia Restituta (received in 1999).

- Knight's Cross of the Order of Polonia Restituta (received in 1981).

- Medal of the Commission of National Education (received in 1980).

- Medal of the Polish Association of Civil Engineers and Technicians in recognition of outstanding achievements in science and engineering, and for service in educa- 
tion of new generation of engineers as well as for an organizational contribution to the Association (received in 2000).

- Medal of the President of Gdańsk and the Governor of Pomerania as well as a number of honorary medals of national universities (Universities of Technology in Poznań and Rzeszów) and foreign universities (Universities of Technology in Kosice and Bratislava).

In addition to sincere congratulations in the occasion of 80th birthday anniversary of Professor Jerzy Ziółko, on behalf of academic and professional communities - all the best wishes of good health and satisfaction of future activities undertaken for weal of science and practice in civil engineering.

Marian Giżejowski

Chairman of Metal Structures Section of Committee for Civil Engineering of Polish Academy of Sciences 
